\title{
NORTHERN PRAIRIE SKINK RANGE EXTENSION IN MANITOBA
}

ARDYTHE McMASTER, 306 Brock Street, Winnipeg, Manitoba, R3N 0Y9.

On 20-22 May, 1978, my husband Don and I, with our two children, pitched our tipi, a homemade replica of a Plains Indian tipi, on a prairie knoll on the high north side of the Assiniboine River nine miles due north of Treherne. The soil there is classified as "Stockton loamy sands",5 loosely sodded with native prairie plants and some creeping juniper Juniperus horizontalis. Here we observed, over a period of three days, perhaps six, but at least two Northern Prairie Skinks Eumeces septentrionalis septentrionalis. We were able to catch some of the skinks, observing their smooth greenish-brown colour with lateral lines of light and dark. Some bore the deep red-orange chin patch which Conant identifies as characterizing the breeding male; some had tails whose tips were clearly darker, indicating a tail tip lost and regrown.2 Most of the skinks we observed were in the act of observing us, having climbed up between the tipi cover and the interior lining and perched atop the lining cords which encircle the tipi interior at about four feet, affording us excellent opportunity to observe them at rest.

We believe these skinks represent sightings outside the recorded range for Manitoba.

First correctly identified by Patch in 1934, the skink was first reported by Criddle in 1919, though a painting of the skink by Norman Criddle is dated 1898.8 49 Logier and Toner list four Manitoba skink localities: Bran- don, Cypress River, Onah and Treesbank. ${ }^{7}$ Cook summarizes the Manitoba population as follows: Onah, a deserted station on the CNR main line about 20 miles east of Brandon, and at four locations along the sandy banks and sandhills north of the Assiniboine River: just east of the junction of the Souris and Assiniboine rivers, north of Stockton, north of Cypress River, and north of Holland. 3

There are 10 specimens preserved in collections, all from north of the Assiniboine River, of which six are from the Aweme-Treesbank area, collected by members of the Criddle family. One University of Manitoba specimen labelled "Aweme district, (Treherne) 20 July 1935" seems confusing, as Treherne is a village nearly 40 miles east of Aweme, on the south side of the Assiniboine. Cook explains that Aweme (the Criddle farm) is no longer shown on most maps and that Treherne was named for easy reference to the general area. ${ }^{3}$ It seems easy to speculate, however, that Treherne was named erroneously, Treesbank having been intended. The Holland report (1961) at SE $1 / 4$ 15-9-11 W.P.M. "about midway between the towns of Austin and Holland" still represents the most easterly record in the literature of skinks in Manitoba.

Assuming the Treherne record to be improperly described, our tipi site, NW $1 / 4$ 19-9-9 W.P.M., is an easterly extension of the recorded range. It is approximately 38 miles east of both 


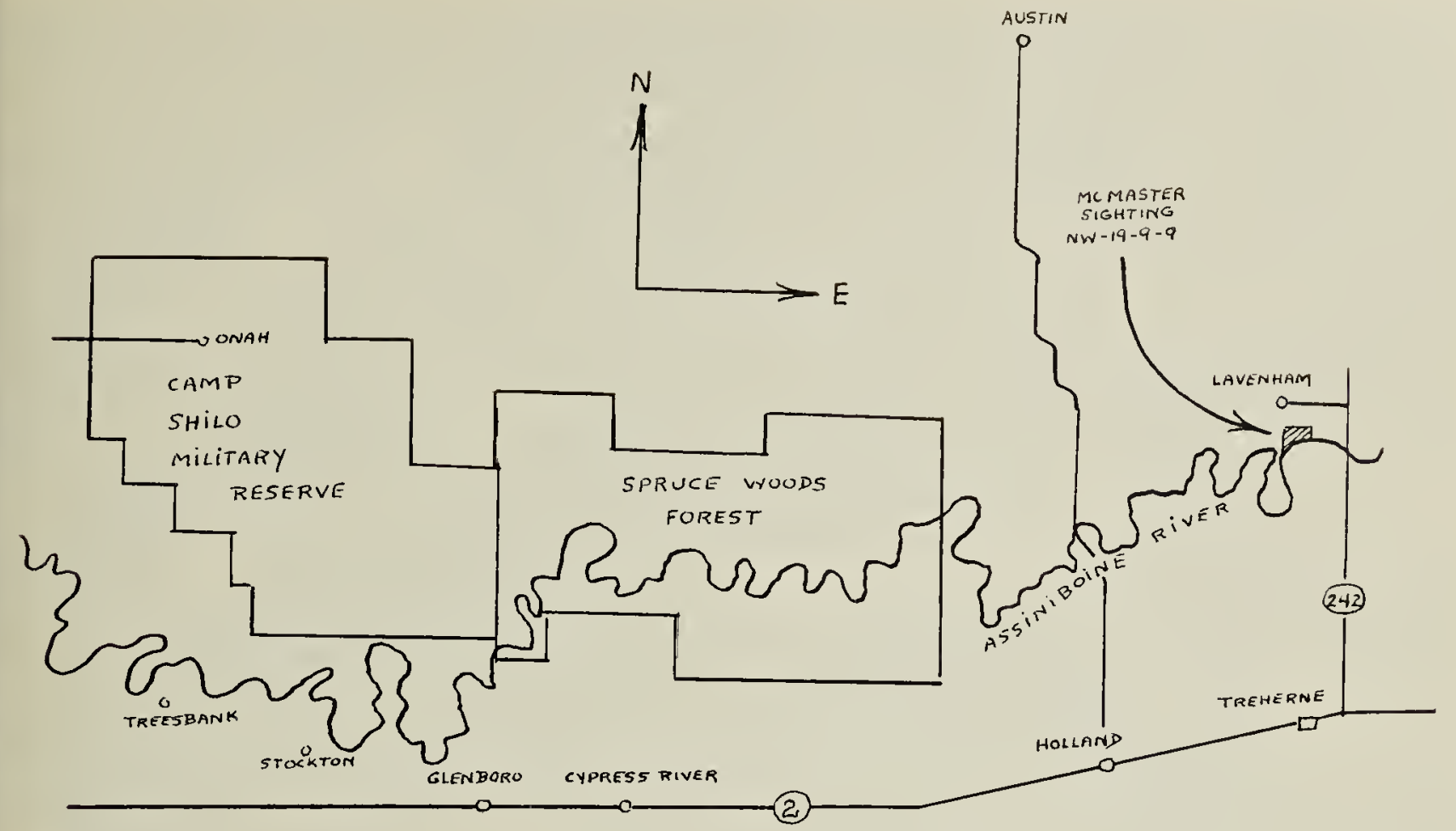

Onah and Treesbank, 22 miles east of Cypress River, and 9 miles east of the Holland sighting. The location horth of the Assiniboine River in sandy soil supports the suggestion by Bird and Cook that, "in less sandy soil the skinks would be unable to burrow deep enough to survive the colder winters". 13 Having compared these records with the soil survey, I find that all are within the classification Stockton loamy sands, with the possible exception of the Cypress River specimens, depending on how far north of the village they were taken. 56 If indeed soil type is the limiting factor in skink distribution in Manitoba, then our skinks were near the eastward boundary of the range, for Stockton loamy sands end abruptly less than two miles east of our tipi site.

I am grateful to Carol A. Scott for her interest, encouragement, and assistance in the preparation of this report.

1BIRD, R. D. 1927. A preliminary ecological survey of the district surrounding the entomological station at Treesbank, Manitoba. Ecology 8(2):207-220.
2CONANT, R. 1975. A field guide to reptiles and amphibians of eastern and central North America. Second edition. Houghton Mifflin Company, Boston. xviii +429 pp.

${ }^{3}$ COOK, F. R. 1964. The Northern Prairie Skink in Manitoba: a possible relic population. National Museum of Canada Natural History Papers No. 24. $11 \mathrm{pp}$.

${ }^{4}$ CRIDDLE, N. 1919. Additional notes on Manitoba turtles, snakes and batrachians. Ottawa Naturalist 32(7):135.

5EHRLICH, W. A., E. A. POYSER and L. E. PRATT. 1957. Report of reconnaissance soil survey of Carberry map sheet area. Manitoba Dept. of Agric. and Immig. Soils Report No. 7. $93 \mathrm{pp}$.

6ELLIS, J. H. and W. H. SHAFER. 1943. Report of reconnaissance soil survey of south-central Manitoba. Manitoba Dept. of Agric. Soils Report No. 4, 146 pp.

7LOGIER, E. B. S. and G. C. TONER. 1961. Check list of the amphibians and reptiles of Canada and Alaska. Second Ed. Royal Ont. Mus. Life Sc. Div. Cont. No. 53. $x+92$ pp.

8PATCH, C. L. 1934. Eumeces in Canada. Copeia 1934(1):50-51.

9SCOTT, C. A. 1978. Pers. comm. 